\title{
Reactive thrombocytosis- etiology and its relationship with different hematological parameters, ESR, \& CRP in Tuberculosis
}

\author{
Garg B. ${ }^{{ }^{*}}$
}

DOI: https://doi.org/10.17511/jopm.2020.i01.11

\author{
1* Bhavana Garg, Assistant Professor, Department of Pathology, Pacific medical college and Hospital, Udaipur, Rajasthan, India. \\ https://orcid.org/0000-0003-0357-0247
}

Background: The measurements of platelet count, mean platelet volume (MPV), WBC are routinely available nowadays. The aim of this study was to determine age dependent aetiology and relationship of these parameters whether they were associated with the known markers of disease activity, erythrocyte sedimentation rate (ESR) and C- reactive protein (CRP) in Tuberculosis. Methods: This descriptive study was done on 500 patients with platelet count $>450,000 / \mu \mathrm{l}$ and the cause being reactive. Platelet count, WBC, MPV, ESR, and CRP were measured the time of hospitalization. Result: Most common cause of reactive thrombocytosis was found to be infection $(28.8 \%)$, tissue damage $(16.4 \%)$, iron deficiency anemia $(16.2 \%)$, malignancy $(9.6 \%)$, inflammation (non-tuberculosis) $(9.4 \%)$, diabetes mellitus $(6.4 \%)$, tuberculosis $(6.0 \%)$ respectively. There was low degree of positive correlation between reactive thrombocytosis with WBC $(r=0.337$, $P=0.06)$ and ESR $(r=.277, P=>0.05)$. Conclusion: This study demonstrated a higher level of platelet count and lower MPV in all the patients having reactive thrombocytosis. The changes in these parameters (platelets count, WBC, MPV, CRP and ESR) may reflect a reaction to the inflammatory condition. Therefore, in endemic areas, the presence of such haematological peripheral blood changes may raise the suspicion of tuberculosis.

Keywords: Erythrocyte sedimentation rate (ESR), Thrombocytosis, Tuberculosis, Reactive thrombocytosis

\section{Corresponding Author}

Bhavana Garg, Assistant Professor, Department of Pathology, Pacific medical college and Hospital, Udaipur, Rajasthan, India.

Email: bhavanagarg203@gmail.com
How to Cite this Article

Garg B. Reactive thrombocytosis- etiology and its relationship with different hematological parameters, ESR, \& CRP in Tuberculosis. Trop J Pathol Microbiol. 2020;6(1):69-75.

Available From

https://pathology.medresearch.in/index.php/jopm/ar ticle/view/405
To Browse

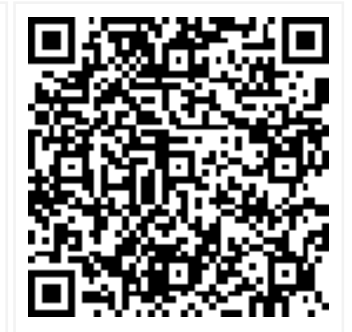

\section{Introduction}

Thrombocytosis refers to a platelet count above the normal value with the widespread use of electronic cell counters and the subsequent availability of a platelet count as part of a 'routine' blood count, thrombocytosis

\section{Manuscript Received} 30-12-2019

Conflict of Interest No

Review Round 1
$10-01-2020$
Funding
Nil

() 2020 by Bhavana Garg and Published by Siddharth Health Research and Social Welfare Society. This is an Open Access article licensed under a Creative Commons Attribution 4.0 International License https://creativecommons.org/licenses/by/4.0/ unported [CC BY 4.0].
Is more often observed as an unexpected finding. Thus, an elevated platelet count has become an important clinical problem for differential diagnosis. Thrombocytosis is classified according to its origin into primary and secondary forms [1]. Primary thrombocytosis occurs in chronic myelopro- 
Liferative and some myelodysplastic disorders [2]. Secondary thrombocytosis is due to a variety of underlying conditions such as acute bleeding, trauma, major surgical procedures, after severe physical exertion, malignancy, chronic infection [3], iron deficiency and in many chronic inflammatory diseases, including tuberculosis.

Tuberculosis (TB) is a major public health problem in India [4]. The differential diagnosis of tuberculosis should be entertained in patients with some abnormal hematological [5] findings. Moreover, hematological parameters are useful indicators of severity in TB infection [6]. CRP is an acute phase protein secreted by the liver in response to inflammatory cytokines. Levels of CRP increase very rapidly in response to trauma, inflammation, infection, tissue necrosis and surgery. ESR is elevated in a wide range of organic disease. ESR is not a specific and diagnostic test for any disease. However, it is helpful in differentiating functional from organic disease. The objective of this study was to study etiology of reactive thrombocytosis and correlate different indices in the TB patients especially with reference to the platelet count, ESR, WBC, and CRP. To establish if thrombocytosis can be used as a marker in TB patients.

\section{Material and Methods}

Study area: The study area selected for the study was tertiary care hospital.

Study period: The study was conducted between the period June 2010 and September 2011 over a period of 16 months.

Study group: A total of 500 patients who had come to OPD or were admitted in Hospital (booked or emergency) having reactive thrombocytosis were taken up for the study.

Study methods: All the samples which were received by the Central Diagnostic Laboratory, with requisition form for investigations from the respective OPD's or Wards and were found to have accidental thrombocytosis. The cause for thrombocytosis was found to be reactive after taking the clinical details from the consulting physician's or surgeons. The information thus collected was compiled in the master chart \& also subjected to statistical analysis. Following parameters were included in my study:
- Histogram- Haemoglobin, Total leukocyte count, Platelet count, Mean platelet volume. They were estimated by automated blood cell counter (Sysmex KX-21, K-1000). Sysmex KX-21 - it performs blood cell count by DC detection method, also k/a Coulter Principle.

- Erythrocyte Sedimentation Rate- Done by Westergren tube method

- C-Reactive Protein-measured by Latex agglutination test using qualitative method based on the principle of agglutination.

Study design: Descriptive study

Sample size: 500 samples (platelet $>450,000 / \mu \mathrm{l}$ )

Procedure of data collection: For the collection of data the ethical clearance was taken from the Human Research Ethical Committee (HREC).

Inclusion criteria: All patients who had come to OPD and was admitted in hospital (booked or emergency) having reactive thrombocytosis (platelet count $>450,000 / \mu \mathrm{l})$.

Exclusion criteria: Patients having platelet count more than 4.5 lakh $/ \mu \mathrm{l}$, but this was normal for their age as in paediatrics. Patient having thrombocytosis due to Myeloproliferative disorders (polycythemia vera, chronic myeloid leukaemia, chronic idiopathic myelofibrosis, essential thrombocytosis). Patient having thrombocytosis which is autonomous (primary) and not reactive (secondary).

Data analysis: Data thus collected was pooled in master chart \& subjected to statistical analysis. Statistical analysis was done using the Cross tabulations for categorical data \& correlation for continuous data in the SPSS ver.19 programme.

\section{Results}

A total of 500 patients with the platelet count $>450,000 /$ ul was observed during the study period. The various underlying conditions associated with reactive thrombocytosis are listed in (Table 1 ).

Table-1: Table showing causes of Reactive Thrombocytosis

\begin{tabular}{|l|l|l|l|}
\hline S. No & \multicolumn{1}{|c|}{ Causes } & \multicolumn{1}{|c|}{ No. of cases } & \multicolumn{1}{|c|}{ Percentage\% } \\
\hline \multirow{2}{*}{2.} & Infections & 144 & 28.8 \\
\hline \multirow{5}{*}{2.} & $\begin{array}{l}\text { Tissue damage } \\
\text { a)Trauma }\end{array}$ & 42 & 8.4 \\
\cline { 2 - 4 } & b) Fracture & 16 & 3.2 \\
\cline { 2 - 5 } & c) Post-operative & 14 & 2.8 \\
\cline { 2 - 5 } & d) Burns & 10 & 2.0 \\
\hline
\end{tabular}




\begin{tabular}{|c|c|c|c|}
\hline \multirow[t]{2}{*}{3.} & $\begin{array}{l}\text { Anemia } \\
\text { a) Iron deficiency anemia }\end{array}$ & 81 & 16.2 \\
\hline & b) Megaloblastic anemia & 1 & 0.2 \\
\hline \multirow[t]{2}{*}{4.} & $\begin{array}{l}\text { Neoplastic } \\
\text { a) Malignant }\end{array}$ & 48 & 9.6 \\
\hline & b) Benign & 2 & 0.4 \\
\hline 5. & Inflammation(non-tuberculosis) & 47 & 9.4 \\
\hline 6. & Diabetes mellitus & 32 & 6.4 \\
\hline 7. & Tuberculosis & 30 & 6.0 \\
\hline 8. & Poisoning & 10 & 2.0 \\
\hline \multirow[t]{2}{*}{9.} & $\begin{array}{l}\text { Haemolytic anemia } \\
\text { a) Thalassemia major }\end{array}$ & 7 & 1.4 \\
\hline & b) Sickle cell anemia & 2 & 0.4 \\
\hline 10. & Post splenectomy & 5 & 1.0 \\
\hline 11. & Hemorrhage & 4 & 0.8 \\
\hline 12. & Myocardial infarction & 2 & 0.4 \\
\hline 13. & CCF (ASO positive) & 1 & 0.2 \\
\hline 14. & Low birth weight & 1 & 0.2 \\
\hline 15. & Drug reaction & 1 & 0.2 \\
\hline Tota & & 500 & 100.0 \\
\hline
\end{tabular}

Almost equal number of cases was studied in both the genders, males (50.8\%) and females (49.2\%). Most common cause of reactive thrombocytosis was Infections (28.8\%), Tissue damage (16.4\%), Iron deficiency anemia (16.2\%), Malignancy (9.6\%), Inflammation (9.4\%) and tuberculosis (6.0\%). Majority of cases were in between 38-56 years (31\%) and $19-37$ years (26\%) (Table 2 ).

Table-2: Number of cases in relation to age group

\begin{tabular}{|l|l|l|l|}
\hline \multicolumn{1}{|c|}{ S.NO } & \multicolumn{1}{|c|}{ Age in years } & \multicolumn{1}{c|}{ No. of cases } & \multicolumn{1}{c|}{ Percentage\% } \\
\hline 1. & $0-18$ years & 105 & 21.0 \\
\hline 2. & $19-37$ years & 129 & 25.8 \\
\hline 3. & $38-56$ years & 155 & 31.0 \\
\hline 4. & $57-75$ years & 97 & 19.4 \\
\hline & $76-94$ years & 14 & 2.8 \\
\hline Total & & 500 & 100.0 \\
\hline
\end{tabular}

Table-3: Correlation of platelet count with Total leucocyte count (TLC) in tuberculosis.

\begin{tabular}{|c|c|c|c|c|c|}
\hline \multirow{2}{*}{\multicolumn{2}{|c|}{$\begin{array}{l}\text { Platelet count range } \\
\times 103\end{array}$}} & \multicolumn{3}{|c|}{ TLC $(/ \mathrm{cmm})$ count in Tuberculosis } & \multirow[t]{2}{*}{ Total } \\
\hline & & \multirow{2}{*}{$\begin{array}{l}4000- \\
11000 \\
11\end{array}$} & \multirow{2}{*}{\begin{tabular}{|l}
$11001-$ \\
20000
\end{tabular}} & \multirow{2}{*}{$\begin{array}{l}20001- \\
30000\end{array}$} & \\
\hline $450-600$ & No. & & & & 24 \\
\hline & $\%$ of Total & $36.7 \%$ & $40.0 \%$ & $3.3 \%$ & $80.0 \%$ \\
\hline \multirow[t]{2}{*}{$601-750$} & No. & 0 & 3 & 1 & 4 \\
\hline & $\%$ of Total & $.0 \%$ & $10.0 \%$ & $3.3 \%$ & $13.3 \%$ \\
\hline \multirow[t]{2}{*}{$751-900$} & No. & 0 & 2 & 0 & 2 \\
\hline & $\%$ of Total & $.0 \%$ & $6.7 \%$ & $.0 \%$ & $6.7 \%$ \\
\hline \multirow[t]{2}{*}{ Total } & No. & 11 & 17 & 2 & 30 \\
\hline & $\%$ of Total & $36.7 \%$ & $56.7 \%$ & $6.7 \%$ & $100.0 \%$ \\
\hline
\end{tabular}

Platelet count ranging from 450000-600000/cmm was seen with WBC $4000-11000 / \mathrm{cmm}$ in 11 cases of tuberculosis (36.7\%). Whereas WBC ranging from $11001-20000 / \mathrm{cmm}$ was seen in 12 cases of tuberculosis $(40.9 \%)$. There was low degree of positive correlation between reactive thrombocytosis and WBC in tuberculosis $\mathrm{r}=0.337, \mathrm{P}=0.06$ (Table 3 ).

There was low degree of positive correlation between reactive thrombocytosis and WBC in tuberculosis $r=0.337, P=0.06$.

Platelet count ranging from 450000-600000/cmm was seen with ESR 21-40 ( $\mathrm{mm} 1 \mathrm{sthr}$ ) in 09 cases of tuberculosis (30.0\%). Whereas ESR ranging from 41-60 ( $\mathrm{mm} 1 \mathrm{sthr}$ ) was seen in 8 cases of tuberculosis $(26.7 \%)$. There was low degree of positive correlation between reactive thrombocytosis and ESR in tuberculosis $r=.277, \mathrm{P}=>0.05$ (Table 4).

\section{Table-4: Correlation of platelet count with ESR in tuberculosis.}

\begin{tabular}{|c|c|c|c|c|c|c|c|c|}
\hline \multicolumn{2}{|c|}{ et count range } & \multicolumn{6}{|c|}{ ESR ( $\mathrm{mm} \mathrm{1st} \mathrm{hr)} \mathrm{in} \mathrm{Tuberculosis}$} & \multirow[t]{2}{*}{ Total } \\
\hline \multicolumn{2}{|r|}{ x103 } & $0-20$ & $21-40$ & $41-60$ & $61-80$ & $81-$ & $121-$ & \\
\hline \multirow[t]{2}{*}{$450-600$} & No. & 2 & 9 & 8 & 2 & 2 & 1 & 24 \\
\hline & $\%$ of Total & $\begin{array}{l}6.7 \\
\%\end{array}$ & $\begin{array}{l}30.0 \\
\%\end{array}$ & $\begin{array}{l}26.7 \\
\%\end{array}$ & $6.7 \%$ & $6.7 \%$ & $3.3 \%$ & $80.0 \%$ \\
\hline \multirow[t]{2}{*}{$601-750$} & No. & 0 & 0 & 0 & 3 & 1 & 0 & 4 \\
\hline & $\%$ of Total & $.0 \%$ & $.0 \%$ & $.0 \%$ & $\begin{array}{l}10.0 \\
\%\end{array}$ & $3.3 \%$ & $.0 \%$ & $13.3 \%$ \\
\hline \multirow[t]{2}{*}{ 751-900 } & No. & 0 & 0 & 1 & 1 & 0 & 0 & 2 \\
\hline & $\%$ of Total & $.0 \%$ & $.0 \%$ & $3.3 \%$ & $3.3 \%$ & $.0 \%$ & $.0 \%$ & $6.7 \%$ \\
\hline \multirow[t]{2}{*}{ Total } & No. & 2 & 9 & 9 & 6 & 3 & 1 & 30 \\
\hline & $\%$ of Total & $\begin{array}{l}6.7 \\
\%\end{array}$ & $\begin{array}{l}30.0 \\
\%\end{array}$ & $\begin{array}{l}30.0 \\
\%\end{array}$ & $\begin{array}{l}20.0 \\
\%\end{array}$ & $10.0 \%$ & $3.3 \%$ & $\begin{array}{l}100.0 \\
\%\end{array}$ \\
\hline
\end{tabular}

There was low degree of positive correlation between reactive thrombocytosis and ESR in tuberculosis $r=.277, \mathrm{P}=>0.05$.

Table-5: Correlation of platelet count with MPV in tuberculosis.

\begin{tabular}{|c|c|c|c|c|}
\hline \multicolumn{2}{|c|}{ Platelet count range $\times 103$} & \multicolumn{2}{|c|}{ MPV (fL) } & \multirow[t]{2}{*}{ Total } \\
\hline & & $<7.2$ & $7.2-11.7$ & \\
\hline \multirow[t]{2}{*}{$450-600$} & No. & 0 & 24 & 24 \\
\hline & $\%$ of Total & $.0 \%$ & $80.0 \%$ & $80.0 \%$ \\
\hline \multirow[t]{2}{*}{$601-750$} & No. & 0 & 4 & 4 \\
\hline & $\%$ of Total & $.0 \%$ & $13.3 \%$ & $13.3 \%$ \\
\hline \multirow[t]{2}{*}{ 751-900 } & No. & 1 & 1 & 2 \\
\hline & $\%$ of Total & $3.3 \%$ & $3.3 \%$ & $6.7 \%$ \\
\hline \multirow[t]{2}{*}{ Total } & No. & 1 & 29 & 30 \\
\hline & $\%$ of Total & $3.3 \%$ & $96.7 \%$ & $100.0 \%$ \\
\hline
\end{tabular}


MPV was normal (7.2-11.7fL) in 24cases of tuberculosis $(80.0 \%)$ with platelet count ranging from $450000-600000 / \mathrm{cmm}$. Whereas MPV was normal in 4cases of tuberculosis (13.3\%) with platelet count ranging from $601000-750000 / \mathrm{cmm}$. There was significant negative correlation between reactive thrombocytosis and MPV in tuberculosis $r=$ $-.561, \mathrm{P}=>0.001$ (Table 5).

There was significant negative correlation between reactive thrombocytosis and MPV in tuberculosis $r=$ $-.561, \mathrm{P}=>0.001$. CRP was positive in 23 cases of tuberculosis $(76.7 \%)$ and negative in 4 cases of tuberculosis $(13.3 \%)$ with platelet count ranging from $450000-69900 / \mathrm{cmm}$. There was low degree of negative correlation $r=-.131, \mathrm{P}=>0.05$ (Table 6). (*Degree of thrombocytosis according to Dinesh Yadav et al) [7].

Table-6: Correlation of platelet count with CRP in tuberculosis.

\begin{tabular}{|l|l|l|l|l|}
\hline \multicolumn{2}{|c|}{$\begin{array}{c}\text { Degree of thrombocytosis } \\
\text { Platelet count range } \times 103\end{array}$} & \multicolumn{2}{|c|}{ CRP } & \multirow{2}{*}{ Total } \\
\cline { 2 - 4 } & Positive & Negative & \\
\hline Mild(450-699) & No. & 23 & 4 & 27 \\
\cline { 2 - 5 } & $\%$ of Total & $76.7 \%$ & $13.3 \%$ & $90.0 \%$ \\
\hline \multirow{2}{*}{ Moderate(700-899) } & No. & 3 & 0 & 3 \\
\cline { 2 - 4 } & $\%$ of Total & $10.0 \%$ & $.0 \%$ & $10.0 \%$ \\
\hline \multirow{2}{*}{ Total } & No. & 26 & 4 & 30 \\
\cline { 2 - 4 } & $\%$ of Total & $86.7 \%$ & $13.3 \%$ & $100.0 \%$ \\
\hline
\end{tabular}

There was low degree of negative correlation $r=$ $-.131, \mathrm{P}=>0.05$.

\section{Discussion}

Until the introduction of electronic blood cell counting instruments, platelet counts were not usually included in the routine complete blood cell count. Now that accurate platelet counts are part of the routine blood cell count, thrombocytosis is being encountered much more frequently [8]. In the present study, the most common cause of reactive thrombocytosis was found to be infection $28.8 \%$, tissue damage $16.4 \%$, iron deficiency anemia $16.2 \%$, malignancy $9.6 \%$, inflammation (nontuberculosis) $9.4 \%$, diabetes mellitus $6.4 \%$, tuberculosis $6.0 \%$, poisoning $2.0 \%$, hemolytic anemia $1.8 \%$, hemorrhage $0.8 \%$, myocardial infarction $0.4 \%$, Low birth weight and drug reaction $0.2 \%$ respectively. The study also showed that among the infections most common was bacterial infection $87.5 \%$, viral $10.4 \%$ and non-specific $2.1 \%$ respectively. In other studies, infection has also been found to be one of the most frequent causes of thrombocytosis, especially in children $[9,10]$.
Wolach et al [11] observed thrombocytosis in $92.5 \%$ of children with pneumonia and empyema. Reactive thrombocytosis was common in a group of 122 patients with active pulmonary tuberculosis, and the degree of platelet elevation correlated significantly with the degree of inflammation [12]. Nagai $T$ et al [13] reported a case of IDA with marked thrombocytosis (platelet> 100,000/cmm) that was complicated by central retinal vein occlusion. However, in present study no case of IDA associated with complications were studied. In the present study reactive thrombocytosis due to TB was found in $6.0 \%$ of the cases. However, Bayness $\mathrm{RD}$ et al [12] have mentioned reactive thrombocytosis was common occurrence due to TB, while according to MC Donald [14] and Omar et al [15] TB was an uncommon occurrence. Though the present study was not designed to assess only aetiology of reactive thrombocytosis, but also the association of reactive thrombocytosis and tuberculosis. TB is a major public health problem in India. Various haematological markers have been used to raise suspicion of TB spondylitis. These markers have also been used prognosticate the efficacy of its treatment. Haematological findings from lymphocytosis, anaemia, a raised ESR and CRP are found in active tuberculosis $[16,17]$. Baynes et al. [12] noted reactive thrombocytosis in pulmonary TB. Muzaffar TM et al. studied that $52.9 \%$ patient with reactive thrombocytosis had TB spine [18]. The platelet count as diagnosis of TB spondylitis has not been adequately researched. The present study aimed at taking into the account various hematological parametersWBC, ESR, MPV CRP, and its correlation with reactive thrombocytosis to access the disease activity, in tuberculosis. In the present study platelet count ranging from 450000$600000 / \mathrm{cmm}$ was associated with WBC 4000$11000 / \mathrm{cmm}$ in $36.7 \%$ of cases of reactive thrombocytosis due to tuberculosis. Whereas WBC ranging from $11001-20000 / \mathrm{cmm}$ was seen in $40.9 \%$ of cases of reactive thrombocytosis due to tuberculosis. There was low degree of positive correlation between them. The occurrence of leukocytosis with thrombocytosis is thought to be the immune responses to tuberculosis [19-21]. Compared to our findings, Banerjee et al [22] found leukocytosis in $28.63 \%$ cases and leucopenia in $2.20 \%$ cases. The degree of thrombocytosis is also associated with markers of inflammation (erythrocyte sedimentation rate and C-reactive protein) [12]. The ESR, a sensitive but not a specific measure of the inflammatory response. 
ESR is known inflammatory marker of active tuberculosis and its prognosticating the response of treatment is well known $[16,18,23-25]$. Platelet count ranging from $450000-600000 / \mathrm{cmm}$ was seen with ESR $21-40$ ( $\mathrm{mm} \mathrm{1st} \mathrm{hr)} \mathrm{in} 30.0 \%$ of cases of reactive thrombocytosis due to tuberculosis. Whereas ESR ranging from 41-60 ( $\mathrm{mm} 1$ st $\mathrm{hr}$ ) was seen in $26.7 \%$ of cases of reactive thrombocytosis due to tuberculosis There was low degree of positive correlation between them. Similar study done by Baynes RD et al [12] found significant positive correlation. They also found that positive correlation is seen whether it is tubercular or non-tubercular inflammation as far as ESR and reactive thrombocytosis is concerned. Banerjee et al and Yaranal et al noted raised ESR in 99 and $98 \%$ of cases respectively [22,23]. While Guo et al. [26] shows an average ESR of $79.4 \mathrm{~mm} / \mathrm{h}$ of their $67 \mathrm{~TB}$ spondylitis patients. Though, in the present study $P$ value was not significant this may be due to the study of only 30 cases as compared to large number of cases in other study. This discrepancy in future might be solved by studying more cases of reactive thrombocytosis in pulmonary tuberculosis. Thus, concluding platelet counts do increase as the ESR increases and therefore suggesting its significance as an inflammatory marker. Recently, many studies have suggested the importance of MPV as an inflammation marker in some chronic inflammatory disorders, such as rheumatoid arthritis (RA), ulcerative colitis (UC), and psoriasis [27]. However, the results have been controversial and only a few studies have investigated the role of MPV in infection and even fewer have studied the role of MPV specifically in TB infection. MPV was normal (7.2-11.7fl) in $80.0 \%$ cases of tuberculosis with platelet count ranging from $450000-600000 / \mathrm{cmm}$. Whereas MPV was normal in $13.3 \%$ cases of tuberculosis with platelet count ranging from $601000-750000 / \mathrm{cmm}$. There was significant negative correlation between reactive thrombocytosis and MPV in tuberculosis $r=-.561$, $P=>0.001$ ( $P$ value significant at 0.01 ). Similar study was done by Baynes RD et al [12] the findings were similar to the present study. He found a significant inverse correlation between the MPV and the platelet count $(r=-054, p<00001)$. He also did the interval estimation suggesting that this relation was non-linear. Several studies investigating the relation between MPV and TB have controversial results. Tozkoparan et al. found that the MPV was higher in patients with active TB than in non-TB subjects [28]. Şahin et al. reported that there was
No statistical difference in MPV values between TB patients' group and non-TB subjects [29]. Thus, irrespective of the results in different studies and over all inverse correlation of MPV and reactive thrombocytosis MPV in future can also be used as an inflammatory marker measured by the easiest and fastest way to determine the disease activity in TB patients. CRP is used commonly as an acutephase reactant and an inflammatory marker. CRP was positive in $76.7 \%$ cases of tuberculosis and negative in $13.3 \%$ cases of tuberculosis with platelet count ranging from 450000-69900/cmm. There was low degree of negative correlation $r=$ -0.131 , $P$ value was not significant. Similar study done by Baynes RD et al [12] found direct correlation. The exact cause cannot be explained at present and study of more cases in future might be helpful. Thus, concluding that hematological and inflammatory parameters do increase in infection, but they are neither specific and nor sensitive for tuberculosis. Many studies have found direct correlation between reactive thrombocytosis and these parameters in tuberculosis as the study group was only the patients having tuberculosis whereas the present study was limited by less number of cases of reactive thrombocytosis having tuberculosis.

\section{Conclusion}

Reactive thrombocytosis is often an incidental or unexpected finding on a complete blood count conducted to evaluate an unrelated condition. It has multifactorial etiology and its correlation with WBC, ESR, CRP, and MPV in the patients treated for tuberculosis at our hospital, the present study have observed correlation between reactive thrombocytosis and these parameters. Elevations of these parameters may raise the suspicion of tuberculosis and patients should be further investigated and followed up for tuberculosis. It is important to mention that thrombocytosis and these various parameters are not specific to tuberculosis, but such simple test can be used as preliminary investigation in locations where other tests like radiology and microbiology are not available. Together these parameters become an indispensable tool for the diagnosis of tuberculosis.

\section{What the study adds to the existing knowledge?}

Till date aetiology of reactive thrombocytosis and its 
Association with heamatological parameters and inflammatory markers in tuberculosishave been studied separately, but the present study contributes altogether to the association of platelet count with WBC, ESR, CRP and MPV in tuberculosis thus concluding that tuberculosis is an important cause of reactive thrombocytosis and assessment of these hematological and inflammatory parameters can be used as an indicator in the diagnosis and follow-up of TB patients.So degree of thrombocytosis, leukocytosis, ESR, and CRP should be monitored in all the patients suspected of having tuberculosis as it has a diagnostic and prognostic significance during anti-tuberculous therapy.

\section{Acknowledgments}

Dr. Menka Shah, Dr. Monica Gupta, Dr. Keyuri Patel, Dr Sanjay Chaudhari, Dr. Faruq Mulla, Dr. Kriti Rathod and Dr. Munira Jhabuawalla all contributed equally to this work and are considered as senior authors. All of the authors contributed to this study as follows. Dr. Menka Shah provided opinions for interpreting results of the study and manuscript preparation. Rest all other authors took parts in the whole progress of this study such as drawing conclusion.

\section{Abbreviations}

Cmm- Cubic Millimetre, CRP- C-reactive protein, ESR-Erythrocyte sedimentation rate, EDTA- Ethylene diamine tetraacitic acid, ET- Essential thrombocythemia (primary thrombocytosis), FLFemtoliter, IDA-Iron deficiency anemia, MPV- Mean platelet volume, $r$ - Coefficient correlation, TBTuberculosis, TLC-Total leukocyte count, WBC- White blood cells.

\section{Reference}

01. Sanchez S, Ewton A. Essential Thrombocythemia, A review of diagnostic and pathologic features. Arch Pathol Lab Med. 2006;130(8)1144-1150.

doi: [Article:https://doi.org/10.1043/15432165(2006)130[1144:ET]2.0.CO;2][Crossref]

02. Vannucchi AM, Barbui T. Thrombocytosis and Thrombosis. Hematology American Society Hematology Education Program. 2007;1;363370.

doi: [Article:https://doi.org/10.1182/asheducation2007.1.363][Crossref]
03. Singh KJ, Ahluwalia G, Sharma SK, Saxena R, Chaudhary VP, Anant $M$. Significance of hematological associations in tuberculosis. JAPI. $2001 ; 49(4) 788-790$.

[Crossref]

04. World Health Organization. WHO Expert committee on tuberculosis ninth report. WHO tech Research Series. 1974;552;1-40.

Available at [Article:https://apps.who.int/iris/handle/ 10665/41095][Crossref]

05. Buss DH, Cashell AW, O'Connor ML, Richards F, Douglas Case LD. Occurence, etiology, and clinical significance of extreme thrombocytosisa study of 280 cases. Am J Med. 1994;96(3)247-253.

doi:[Article:https://doi.org/10.1016/0002-9343(94) 90150-3][Crossref]

06. F Şahin, E Yazar, and $\mathrm{P}$ Yıldız. Prominent features of platelet count, plateletcrit, mean platelet volume and platelet distribution width in pulmonary tuberculosis. Multidisciplin Resp Med. 2012;7(38).

doi: [Article:https://doi.org/10.1186/2049-6958-738][Crossref]

07. Bozoky G, Ruby E, Góhér I, Tóth J, Mohos A. Hematologic abnormalities in pulmonary tuberculosis. Orv Hetil. 1997;138(17)10531056.

[Crossref]

08. Yadav D, Chandra J, Sharma S, Singh V. Clinicohematological Study of Thrombocytosis. Indian J Pediatr. 2010; 77(6)643-647.

doi: [Article:https://doi.org/10.1007/s12098-0100091-4][Crossref]

09. Santhosh?Kumar CR, Yohannan MD, Higgy KE, Al?Mashhadani SA. Thrombocytosis in adultsanalysis of 777 patients. J Intern Med. 1991;229(6)493-495.

doi:[Article:https://doi.org/10.1111/j.1365-2796. 1991.tb00383.x][Crossref]

10. MC Donald TP. A comparison of platelet size, Platelet count $35 \mathrm{~s}$ incorporation as assay for thrombopoietin. Br J Hematol. 1976;34(2)257267.

doi:[Article:https://doi.org/10.1111/j.1365-2141. 1976.tb00196.x][Crossref]

11. Jain A. Tuberculosis of the spine a fresh look at an old disease. JBJS (Br). 2010;92(7)905-913. doi:[Article:https://doi.org/10.1302/0301-620X. 92B7.24668][Crossref] 
12. Omar M, Jogessar VR, Kamder MC. Thrombocytosis associated with tuberculosis peritonitis tubercle. Elsevier. 1983;64(4)295296.

doi: [Article:https://doi.org/10.1016/00413879(83)90027-2][Crossref]

13. Wolach B, Morag $H$, Drucker M, Sadan N. Thrombocytosis after pneumonia with empyema and other bacterial infections in children. Pediatr Infect Dis J. 1990;9(10)718-721.

doi: [Article:https://doi.org/10.1097/00006454199010000-00007][Crossref]

14. Schlossberg D. Tuberculosis and nontuberculous mycobacterial infections. 4th Ed, Philadelphia, Pennsyvania, United States of America- WB Saunders Company. 1999.

[Crossref]

15. Nagai T, Komatsu N, Sakata Y, Miura Y, Ozawa $\mathrm{K}$. Iron deficiency anemia with marked thrombocytosis complicated by central retinal vein occlusion. Intern Med. 2005;44(10)10901092.

doi:

[Article:https://doi.org/10.2169/internalmedicine.44. 1090][Crossref]

16. Wilson D, Badri M, Maartens G. Performance of serum C-reactive protein as a screening test for smear negative tuberculosis in an ambulatory high HIV prevalence population. PLoS ONE. $2011 ; 6(1) 5248$.

doi:[Article:https://doi.org/10.1371/annotation/53a

56437-a810-4373-baee-16685ec20b2f][Crossref]

17. Sutor AH. Thrombocytosis in childhood. Sem Thromb Hemost. 1995;21(3)330-339.

doi: [Article:https://doi.org/10.1055/s-20071000654][Crossref]

18. Muzaffar TM, Shaifuzain AR, Imran $Y$, Haslina MN. Haematological changes in tuberculosis spondylitis patients at the hospital university. Southeast Asian J Trop Med Publ Health. 2008;39(4)1997-2000.

[Crossref]

19. Singh KJ, Ahulwalia G, Sharma SK, Saxena R, Chaudhary VP, Anant $M$. Significance of hematological manifestations in patients with tuberculosis. J Asso Physicians Ind. $2001 ; 49 ; 788-794$.

[Crossref]
18. Baynes RD, Bothwell TH, Flax H, McDonald TP, Atkinson $\mathrm{P}$, Chetty $\mathrm{N}$, et al. Reactive thrombocytosis in pulmonary tuberculosis. J Clin Pathol. 1987;40(6)676-679.

doi:

[Article:https://dx.doi.org/10.1136\%2Fjcp.40.6.676] [Crossref]

19. Tozkoparan E, Deniz O, Ucar E, Bilgic H, Ekiz K. Changes in platelet count and indices in pulmonary tuberculosis. Clinic Chem Lab Med. 2007;45(8);1009-1013.

doi:

[Article:https://doi.org/10.1515/CCLM.2007.194]

[Crossref]

20. Olaniyi JA, Aken, Ova YA. Bone marrow findings in patients with pulmonary tuberculosis. Afr J Med Sci. 2003;32(2)155-157.

[Crossref]

21. Banerjee M, Chaudhary BL, Shukla S. Hematological profile among pulmonary tuberculosis patients in tertiary care hospital. Int J Bioassays. 2015;4(5)3900-3902.

[Crossref]

22. Yaranal PJ, Umashankar T, Harish SG. Hematological Profile in Pulmonary Tuberculosis. Int J Health Rehabil Sci. 2013;2(1)50-55. [Crossref]

23. Dunn R. The medical management of spinal tuberculosis. SA Orthop J. 2010;9(1)37-41. 25 [Crossref]

24. Ukpe IS, Sothern L. Erythrocyte sedimentation rate values in active tuberculosis with and without HIV co-infection. SAMJ. 2006;96(5)427428.

[Crossref]

25. Guo LX, Ma YZ, Li HW, Xue HB, Peng W, Luo XB. Variety of ESR and C-reactive protein levels during peri-operative period in spinal tuberculosis. PubMed Zhonggno Gu Shang. 2010;3(23)200-202.

[Crossref]

26. Gasparyan AY, Ayvazyan L, Mikhailidis DP, Kitas GD. Mean platelet volume- a link between thrombosis and inflammation?. Curr Pharm Des. $2011 ; 17(1) 47-58$.

doi:

[Article:https://doi.org/10.2174/1381612117950498

04][Crossref] 